\title{
Mưže být "non-alcoholic fatty liver disease" nezávislým per se rizikovým faktorem mimojaterních onemocnění? - editorial
}

\author{
Jiří Ehrmann, Vlastimil Procházka \\ II. interní klinika-gastro-enterologická a hepatologická LF UP a FN Olomouc \\ Komentář k | Editorial on \\ Vašura A et al. Adiponektin u nemocných s metabolickým syndromem a chorobami jater, \\ žlučových cest a pankreatu. Vnitř Lék 2017; 63(12): 945-948.
}

\section{Úvod}

Dnes je již celosvětově akceptováno, že nárůst počtu případů relativně nové nozologické jednotky NAFLD (non-alcoholic fatty liver disease) souvisí s celosvětovou epidemií nadváhy a obezity a s jejími průvodními metabolickými projevy, především inzulinovou rezistencí a dalšími projevy metabolického syndromu. Podle doporučení EASL (The European Association for the Study of the Liver) z roku 2016 je jednotka NAFLD charakterizována nadměrnou akumulací tuku v játrech - steatózou spojenou s inzulinovou rezistencí a přitomností steatózy ve více než $5 \%$ hepatocytů dle histologického vyšetření nebo obsahem tuku nad 5,6\% objemu jaterní tkáně podle protonové MR spektroskopie. NAFLD zahrnuje 2 patologicky odlišné stavy s odlišnou prognózou: nealkoholovou prostou steatózu (NAFL - non-alcoholic fatty liver) a nealkoholovou steatohepatitidu (NASH - non-alcoholic steatohepatitis). NASH pokrývá široké spektrum pokročilosti onemocnění zahrnující steatohepatitidu, fibrózu, cirhózu a hepatocelulární karcinom (hepatocellular carcinoma - HCC) [1].

To, že je onemocnění NAFLD, mocně sdružené s metabolickým syndromem, dnes celosvětově bez ohledu na pohlaví a věk nejčastější prríčinou chronického jaterního onemocnění, je známo a všeobecně akceptováno. Na úrovni vědeckých důkazů rovněž je, že hlavními příčinami úmrtí nemocných s NAFLD jsou choroby kardiovaskulární a malignity [2]. Není proto překvapující, že se výzkumný záměr v poslední době obrací na otázku, zda NAFLD nemůže být nezávislým, per se rizikovým faktorem mimojaterních onemocnění. Že obezita, hypertenze, dyslipidemie a diabetes mellitus 2. typu (DM2T), tedy hlavní komponenty metabolického syndromu, jsou rizikovými faktory civilizačních chorob, je mimo jakoukoliv diskusi, ale na NAFLD se stále pohliží jako na sice častou jaterní komplikaci metabolického syndromu, nicméně rizikovou jen $\mathrm{z}$ hlediska progrese jaterního poškození, tedy vzniku jaterní fibrózy, cirhózy, resp. HCC.

Obecně je NAFLD prozánětlivým stavem s dysfunkcí cyklu tuková tkáň - játra. Dochází k nadprodukci inzu- linu, hyperglykemii, dyslipidemii, ale také k nárůstu karcinogenních růstových faktorů (IGF1, VEGF), prokoagulačních faktorů a prozánětlivých cytokinů (např. CRP, IL6, TNFa, osteopontin) [1]. V důsledku všech těchto i dalších stavů a jejich kombinací může dojít k mimojaterním projevưm NAFLD.

Amstrong et al publikovali v roce 2014 metaanalýzu výsledků 46 studií (retrospektivních i prospektivních) provedených v letech 1999-2013 týkajících se problematiky mimojaterních projevů NAFLD [3]. Nicméně doporučení pro klinickou praxi z nich vyplívající spočívají zatím v preventivním kardiologickém vyšetření, vyloučení poruch metabolizmu uhlovodanů, vyšetření stolice na okultní krvácení (OK), ev. jiného screeningového vyšetření kolorektálního karcinomu u nemocných s NAFLD. Hlavním problémem studií, které měly ve valné většině charakter klinicko-epidemiologický, byla nejednotnost diagnostiky NAFLD. $V$ některých studiích byla diagnostika NAFLD jaterní biopsií, v jiných kombinovanými klinicko-laboratorními testy s 33-91\% senzitivitou, resp. 47-94\% specificitou. Např. Nash/Test (Poynard 2006 - věk, pohlaví, BMI, TG, GGT, ALT, AST, bilirubin), NASH Diagnostics (Younossi 2008 - adiponektin, rezistin, cytokeratin 18), NASH Model of NAFLD Diagnostic Panel (Younossi 2011 - DM2T, pohlaví, BMI, TG, cytokeratin-18). Téměř vždy byla $v$ diagnostice NAFLD použita ultrasonografie (USG), ev. jiná zobrazovací technika, resp. měření elasticity jaterní tkáně. Jinou otázkou metaanalýzy bylo, která z komponent NAFLD je pro vznik mimojaterních komplikací nejrizikovější. Zdá se, že je to NASH. Limitací studií byla také jejich krátkodobost a obecně nižší validita studií retrospektivních. Významným limitem studií pro důkaz kauzality mimojaterních projevů $v$ důsledku NAFLD ale bylo, že nemocní byli sledováni až od vzniku klinických projevů mimojaterního onemocnění. $Z$ tohoto pohledu je pozoruhodná práce Paise et al z roku 2016 [4]. V ní se demonstruje, že jaterní steatóza stanovená užitím FLI (Fatty Liver Index; Calori) je asociovaná s tloušt'kou komplexu intimy-medie karotických arterií (carotic in- 
tima-media thickness - C-IMT) a že tento parametr predikující preaterosklerotické léze proporcionálně narůstá s nárůstem FLI a že tato asociace je pro vznik arteriosklerózy nezávislá na tradičních kardiometabolických faktorech. Jaterní steatóza podle této studie identifikuje pacienty s vyšším C-IMT lépe než DM2T nebo dyslipidemie. Nemocní bez jaterní steatózy měli nižší bazální a follow up C-IMT, zatím co ti, kteří měli steatózu, měli vyšší follow up C-IMT hodnoty. Steatóza predikuje výskyt př́tomnosti karotických plátů v dlouhodobém sledování a je asociovaná s vyšším kardiovaskulárním rizikem ve všech obdobích, tedy jak v základních, tak i v průběhu sledování při hodnocení metodou FRS (Framingham Risc Score). Na druhé straně signifikantní fibróza nebyla prokázaná coby prediktivní znak vývoje cévní př́hody. Výsledky studie naznačují, že zatímco fibróza je nejvzdáleněji asociovaná s nárůstem kardiovaskulární mortality, steatóza i s nízkým stupněm zánětlivé infiltrace hraje důležitou roli ve výskytu a progresi časných stadií aterosklerotických lézí. Výsledky studie podporují kritickou roli jaterní steatózy v progresi arteriosklerotických onemocnění, a steatóza je tedy do značné míry nezávislým faktorem tradičních rizikových faktorů.

Z metaanalýzy studií provedené Armstrongem et al vyplývají pro klinickou praxi tyto závěry mimojaterních projevů NAFLD/NASH.

\section{NAFLD a kardiovaskulární onemocnění}

Ischemická choroba srdeční a cévní mozkové příhody jsou celosvětově nejčastější příčinou úmrtí v důsledku kardiovaskulárních onemocnění. Rizikové faktory, tj. abdominální obezita, arteriální hypertenze, DM2T a dyslipidemie jsou dobře známé. Stejné rizikové faktory byly prokázány i u metabolického syndromu a NAFLD. To přináší otázku, zda je NAFLD symptomem či důsledkem metabolického syndromu. Velké množství studií se zabývalo právě touto otázkou, většina došla k závěru, že kardiovaskulární onemocnění, stejně jako NAFLD jsou následkem či komplikací metabolického syndromu.

Úhrnně lze konstatovat, že nemocní s NAFLD s sebou nesou nezávislý rizikový faktor pro vznik kardiovaskulárního onemocnění a že riziko mortality $v$ důsledku kardiovaskulárního onemocnění je vyšší u těch z nich, kteří mají NASH, ve srovnání s těmi, kteří mají jen prostou steatózu. Další výzkum je třeba zaměřit na prospektivní studie dlouhodobého sledování nemocných s NAFLD, na sjednocení metod detekce komponent NAFLD/NASH a na studie týkající se časných stadií kardiovaskulárních chorob/NAFLD [5].

\section{NAFLD a diabetes mellitus 2. typu}

Ultrasonograficky (USG) diagnostikovaná NAFLD je sdružená s 2-5krát vyšším rizikem vzniku DM2T po zohlednění životního stylu a přítomnosti jiných komponent metabolického syndromu. Do budoucna je třeba studiemi potvrdit, zda riziko vzniku DM2T u osob s NAFLD existuje i u neasijské populace. Dále zda NASH s event. s fibrózou je větším rizikem pro vznik DM2T než prostá steatóza. Také není jednota laboratorní detekce glukó- zové intolerance pro zařazení osob do studií NAFLD coby nezávislého faktoru pro vznik DM2T [2].

\section{NAFLD a onemocněni ledvin}

Choroby ledvin představují závažný celosvětový zdravotní problém, a to zejména u osob s hypertenzí a diabetes mellitus. To je také důvod předpokládaného 7\% nárůstu jejich incidence. Vzhledem $\mathrm{k}$ asociaci NAFLD a metabolického syndromu patří i onemocnění ledvin k mimojaterním projevům NAFLD. Osoby s USG diagnostikovanou NAFLD mají 1,5-2krát vyšší riziko onemocnění ledvin než zdravá populace. Do budoucna je také třeba zjistit, do jaké míry zhoršuje př́tomnost NAFLD funkci již poškozených ledvin [6].

\section{NAFLD a kolorelktální karcinom}

Kolorektální karcinom je celosvětově třetím nejčastějším nádorem s odhadem 1,2 milionů nových prípadů ročně. $\mathrm{O}$ jeho vztahu $\mathrm{k}$ metabolickému syndromu bylo publikováno množství prací, nicméně pro nedostatek dobře dokumentovaných, prospektivních a minimálně 10 roků trvajících studií nelze vztah mezi NASH coby samostatného nezávislého faktoru a vznikem kolorektálního karcinomu zatím potvrdit [7,8].

\section{NAFLD a endolkrinopatie, syndrom polycystických ovarií, syndrom spánkové apnoe a osteoporóza}

Výzkumná pozornost je věnovaná asociaci NAFLD s endokrinopatiemi (zejména s hypofunkcí štítné žlázy, hypogonadizmem, hypopituitarizmem), syndromem polycystických ovarií, syndromem spánkové apnoe a osteoporózou. Nicméně, výsledky jsou limitovány retrospektivním charakterem většiny těchto klinicko-epidemiologických studií, i když jsou důležitým základem pro další výzkum [9-11].

Otevřená je rovněž otázka, do jaké míry NAFLD vzniklá z jiných prríčin než v důsledku metabolického syndromu může být rizikovým faktorem pro mimojaterní projevy.

\section{Závěry pro praxi}

- stoupající incidence NAFLD, i když hlavně v související s nárůstem incidence metabolického syndromu, otevřela $v$ posledním desetiletí otázku mimojaterních projevů NAFLD

- intenzivně se studuje, zda některé mimojaterní projevy nevznikají v důsledku NAFLD coby nezávislého faktoru, tedy $v$ důsledku NAFLD per se

- důkazy postavené na validních studiích tuto hypotézu podporují u chorob kardiovaskulárních a DM2T - u jiných stavů zatím jednoznačné důkazy neexistují

- pro klinickou praxi to znamená nepohlížet na NADLD jen z hlediska rizika progrese jaterního poškození, ale také jako na nezávislý rizikový faktor kardiovaskulárního onemocnění nebo vzniku DM2T - z dalších mimojaterních projevů NAFLD, coby nezávislého rizikového faktoru, se intenzivně studují zejména kolorektální karcinom, onemocnění ledvin, některé endokrinopatie, syndrom spánkové apnoe a osteoporóza 


\section{Shrnuti}

Práce Vašury et al týkající se role metabolického syndromu a adiponektinu u chorob hepatobiliárních a pankreatu je aktuální. Adiponektin syntetizovaný predominantně buňkami tukové tkáně je důležitým regulátorem vztahu mezi tukovou tkání a játry, ale i jinými orgány, např. pankreatem. Významné je rovněž stanovení sérové hladiny adiponektinu v detekci NASH, choroby, na kterou nelze dnes pohližet jen jako na málo významné onemocnění, ale naopak jako na potenciální stav rozvoje závažného jaterního poškození, ale i onemocnění mimojaterních [12].

\section{Literatura}

1. EASL-EASD-EASO Clinical Practice Quidelines for the management of non-alcoholic fatty liver disease. J Hepatol 2016; 64(6): 13881402. Dostupné z DOI: <http://dx.doi.org/10.1016/j.jhep.2015.11.004>.

2. Angulo P. Long-term mortality in non-alcoholic fatty liver disease: is liver histology a fany prognostic significance? Hepatology 2010; 51(2): 373-375. Dostupné z DOI: <http://dx.doi.org/10.1002/ hep.23521>. Erratum in Hepatology 2010; 51(5): 1868.

3. Amstrong MJ, Adams LA, Syn WK et al. Extrahepatic complications of non-alcoholic fatty liver disease. Hepatology 2014; 59(3): 1174-1197. Dostupné z DOI: <http://dx.doi.org/10.1002/hep.26717>.

4. Pais R, Giral P, Khan JF et al. Fatty liver is an independent predictor of early carotic atherosclerosis. J Hepatol 2016; 65(1): 95-102. Dostupné z DOI: <http://dx.doi.org/10.1016/j.jhep.2016.02.023>.

5. Siddiqui MS, Sterling RK, Kuketic VA et al. Association between high-normal levels of alanin aminotransferase and risk factors of atherogenesis. Gastroenterology 2013; 145(6): 1271-1279.e1-3. Dostupné z DOI: <http://dx.doi.org/10.1053/j.gastro.2013.08.036>.
6. Targher G, Bertolini L, Rodella S et al. Relationship between kidney function and liver histology in subjects with nonalcoholic steatohepatitis. Clin J Am Soc Nephrol 2010; 5(12): 2166-2171. Dostupné z DOI: <http://dx.doi.org/10.2215/CJN.05050610>.

7. Wong VW, Wong GL, Tsang SW et al. High prevalence of colorectal neoplasm in patients with non-alcoholic steatohepatitis. Gut 2011; 60(6): 829-836. Dostupné z DOI: <http://dx.doi.org/10.1136/ gut.2011.237974>.

8. Hwang ST, Cho YK, Park JH et al. Relationship of non-alcoholic fatty liver disease to colorectal adenomatous polyps. J Gastroenterol Hepatol 2010; 25(3): 562-567. Dostupné z DOI: <http://dx.doi.org/10.111 1/j.1440-1746.2009.06117.x>.

9. Pagdala MR, Zein CO, Dasarathy $S$ et al. Prevalence of hypothyreoidism in nonalcoholic fatty liver disease. Dig Dis Sci 2012; 57(2): 528 534. Dostupné z DOI: <http://dx.doi.org/10.1007/s10620-011-2006-2>.

10. Brzowska MM, Ostapowicz G, Weltman MD. An association between non-alcoholic fatty liver disease and polycystic ovaria syndrome. J Gastroenterol Hepatol 2009; 24(2): 243-247. Dostupné z DOI: <http://dx.doi.org/10.1111/j.1440-1746.2008.05740.x>.

11. Musso G, Cassader M, Olivetti $C$ et al. Association of obstructive sleep apnoea with the presence and severity of non-alcoholioc fatty liver disease. A systematic review and metaanalisis. Obes Rev 2013; 14(5): 417-431. Dostupné z DOI: <http://dx.doi.org/10.1111/obr.12020>.

12. Ehrmann J, Aiglová K, Vrzalová D et al. Mimojaterní projevy NAFLD (non-alcoholic fatty liver disease). Jde o příčinnou souvislost? Interní Med 2017; 19(2): 72-77.

prof. MUDr. Jiř́ Ehrmann, CSc. هehrmanj@fnol.cz

II. interní klinika - gastro-enterologická a hepatologická LF UP a FN Olomouc

www.fnol.cz

Doručeno do redakce 17. 8. 2017 